\title{
Waste management for achieving sustainable management of water and sanitation in Universitas Sebelas Maret Indonesia
}

\author{
Ravik Karsidi ${ }^{1}$, Okid Parama Astirin ${ }^{2}$, Winny Astuti ${ }^{3}$ \\ ${ }^{1}$ Rector Universitas Sebelas Maret, Campus UNS Kentingan, Surakarta, Indonesia \\ ${ }^{2}$ Department of Biology, Faculty of Mathematics and Natural Science UNS, Coordinator of Green Campus Team Universitas \\ Sebelas Maret Indonesia \\ ${ }^{3}$ Study Program of Urban and Regional Planning, Faculty of Engineering UNS, Chairman of Green Campus Team \\ Universitas Sebelas Maret Indonesia
}

\begin{abstract}
Universitas Sebelas Maret (UNS) is the biggest university in Surakarta Central Java Indonesia, which was established on March $11^{\text {th }}, 1976$ through Presidential Decree No. 10 of 1976. Commitmen of UNS toward Green Campus began in 2012 by Rector Decree $7^{\text {nd }}$ of August 2012. Land size of UNS, whis is only 60 ha becomes constraints in development of Green Campus Initiatives. In 2030 agenda of Sustainable Development Goals gives attention to huge increased of urbanization thus cities and human settlements face the problems of high density, economies of agglomeration link economy, energy, environment, science, technology and social and economic output [2]. The Problem of Water and Sanitation becomes big issues of Sustainable Development Goals (SDGs), which is stated in the Goal 6 out of 17 Goals. Goal 6 not only addresses Clean water sanitation and health but also quality and sustainability of water resources all over the world. Universitas Sebelas Maret is one of Campus in Indonesia, which has awareness toward water and sanitation, especially related to the problem of waste. Liquid waste has become problems for a long time in UNS, when domestic liquid waste has come from residential areas surrounding campus passed through the lake in campus before finally flowing to Bengawan Solo River. This causes euthropication and sedimentation of the lake of UNS, which had impact on extremelly decreased the function of the pond estetically and functionally. By partnership with the Ministry of Public Works anad Spatial Planning in 2017, UNS has built Integrated Waste Water Treatment, which treats domestic liquid waste from residential area surrounding campus and internal campus becomes recycled clean water. In spite of that, UNS also treats organic waste of fall leafs through composting units and manages chemical hazardous waste according to the Indonesian regulation issued by Ministry of Environment. Several efforts of UNS related to Waste Management have contribution to achieving SDGs especially Goal 6: ensure availability and sustainable management of water a sanitation for all [2]. This contributes for improving water quality by reducing pollutions, dumping, minimizing chemical hazardous waste, increasing recycled and safe reuse of water on Campus.
\end{abstract}

\section{Introduction}

Global environment degradation has increased awareness of people all over the world in all sectors of development including education sector as an agent of change and center for Information Technology. Commitment of Universitas Sebelas Maret (UNS) in improving environment to create more livable and sustanable living on campus, has been expressed through Green Campus Programs. Problem of Waste in campus becomes important issues, which has to be managed for achieving Goal 6 of Sustainable Development Goals: ensure availability and sustainable management of water a sanitation for all [2]. Types of waste in UNS generated campus activities are as follows: liquid domestic waste, toxic liquid waste contains B3 (hazardous toxic waste), organic solid waste especially from falling leaves and domestic solid waste. These wastes need proper waste management, to avoid environmental degradation, decreased of estetic and function

\section{Waste management in Universitas Sebelas Maret}

Several programs related to management of waste are conducted for achieving Green Campus. Those programs are: Recycling Program for University

*Corresponding author: ravikkarsidi@yahoo.com 
waste; toxic waste recycling; Organiz waste treatment' and inorganic waste treatment.

\subsection{Recycling program for university waste}

Some efforts of UNS related to Recycling Program for University Waste have been expressed in program of recycling domestic liquid waste for reproducing standard quality of water. Therefore, the recyclng

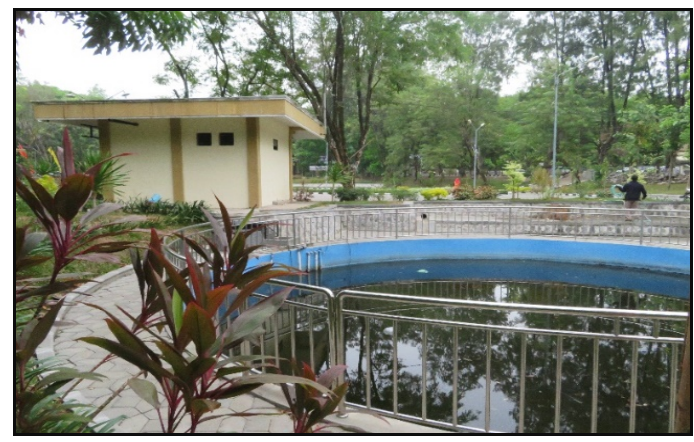

Fig. 1. Recycle water pond resulted from the process of Domestic Liquid Waste Water Treatment Instalation Universitas Sebelas Maret, Indonesia reduces consumption of ground water in campus. The domestic liquid waste water can be reused after along process of waste water treatment for lowering concentration of pollutan's parameters, which cause water pollution. Therefore, this process reduces the pollutans absorbed by the environment thus quality of environment in campuswill be improved.

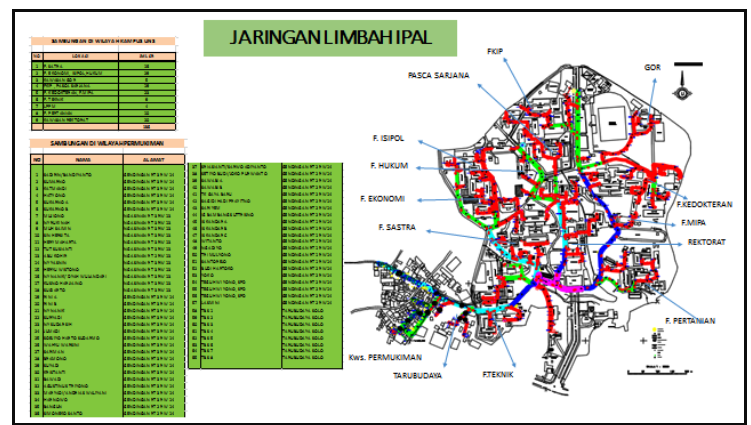

Fig. 2. Coverage area of Domestic Liquid Waste Water Treatment Instalation (IPAL)

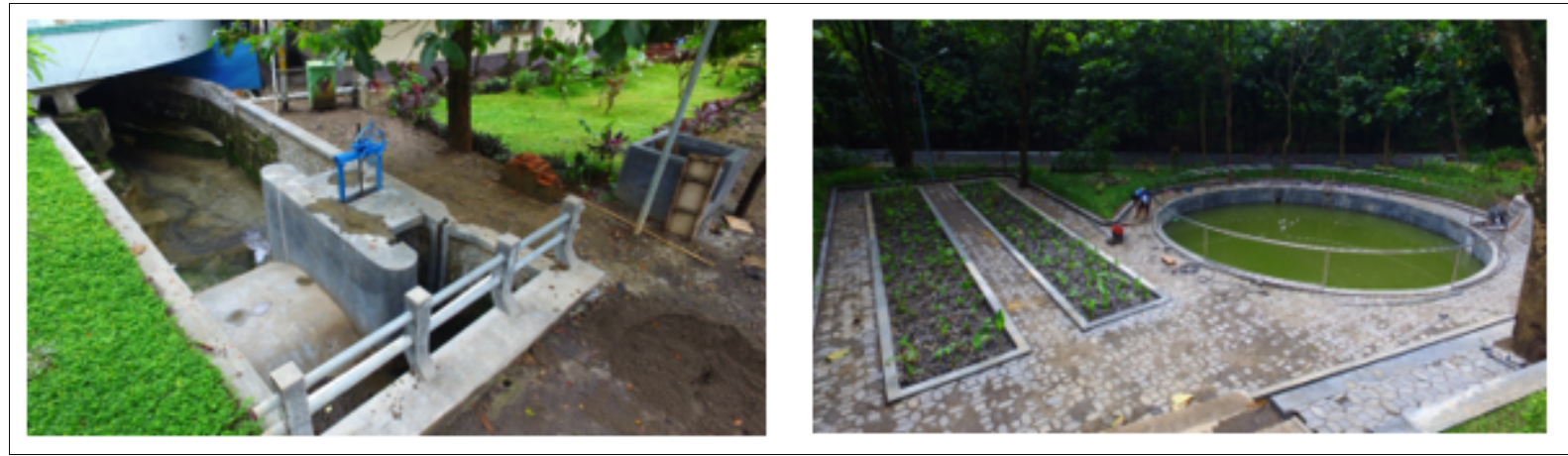

Fig. 3. One of control ponds in Domestic Waste Water Treatment Instalation Universitas Sebelas Maret, Indonesia

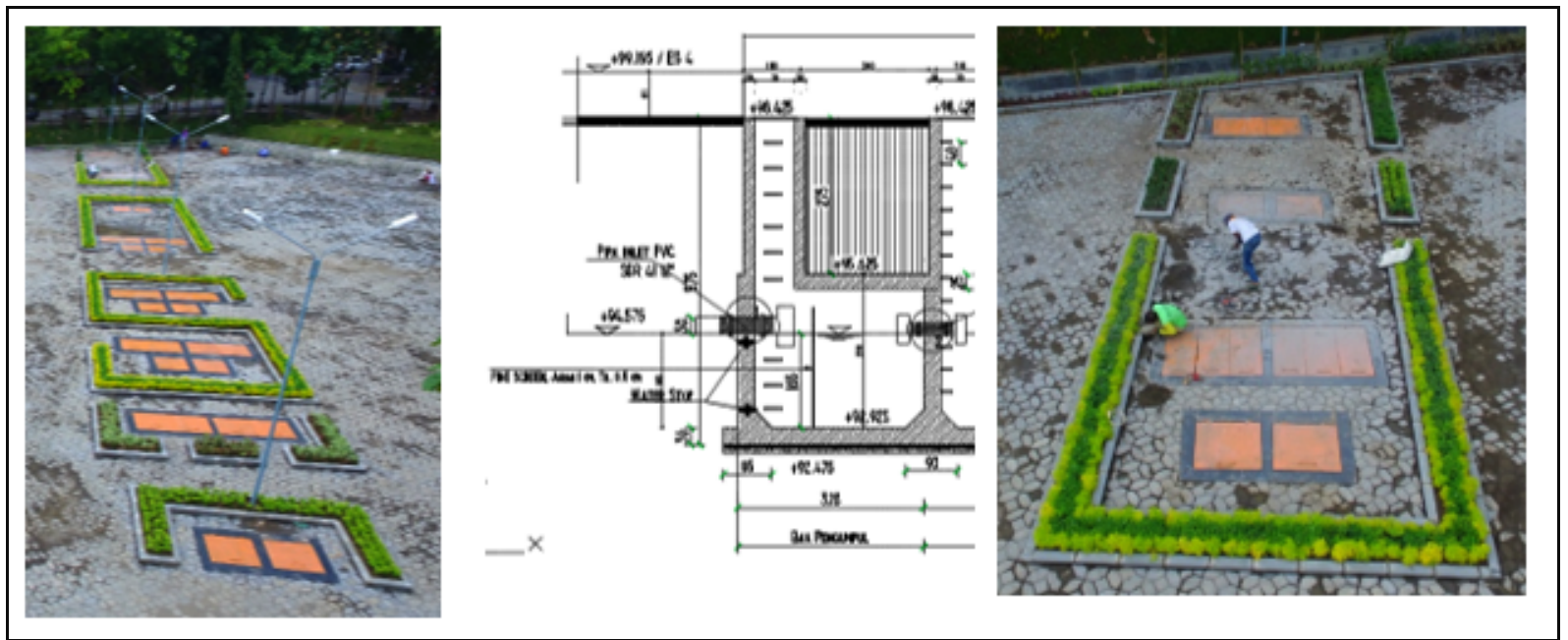

Fig. 4 . Unit of unaerob domestic liquid waste water treatment UNS. 
For a long time UNS has problems of domestic liquid waste water. The sources of domestic liquid waste are not only resulted from activities in campus but also from residential areas in 5 (five) subdistrict (RW) in RW 10, RW 11, RW 12, RW 13, RW 14 in Jebres District, who used to throw their domestic liquid waste to drainage system, which ends in the Pond of UNS. This causes decreasing quality of water of Bengawan Solo River, which flows to the Ponds was below the standard of water quality. In 2017, UNS, funded by Ministry of Public Works, has built Domestic Liquid Waste Water Treatment Instalation (IPAL). In which the installation processes the domestic liquid waste. The capacity of IPAL is 1.293,60 M3/day resulted from student liquid waste of 550,34 M3/day, 306,47 M3/day from lecturers and staff liquid waste and 436,80 M3/day from residential area liquid waste of Jebres District [4].

This instalation operates unaerob method and therefore it is treated in the aerobic recycle water pond (Fig. 1). The liquid waste, which has been processed is analyzed periodically to make sure the Waste Water Treatm3ent Instalation (IPAL) is well performed in processing the waste water. Indicators of well-performed IPAL is the threshold of standard quality of water. The recycle water resulted from IPAL can be used for watering the parks in campus.
These prosesses contribute for conservation of water resources in campus as a part of Green Campus Program.

\subsection{Toxic waste recycling}

Management of toxic waste recycling is very important to save environment. In UNS, there are several working units, which dominantly produce toxic waste such as Faculty of Agriculture, Faculty of Engineering, Faculty of Medicine, Faculty of Matematic and natural science, Faculty of Education Science, Units of Center of Laboratory. As Education Laboratory play important roles for improving quality of students education and research of lecturers. In 2009 UNS has built Integrated Toxic Waste Recycle Instalation, which integrated management of toxic waste produced from Faculty of Mathematic and Natural Science (MIPA) and Faculty of Medicine. However, this instalation has not been effectively worked. Right now, the toxic waste is treated by collection of toxic waste into toxic tank for decomposition process in the Center of Laboratory in MIPA Faculty. This process is conformed to the Regulation of Republic of Indonesia no 101 / 2014 related to Management of toxic waste[1].

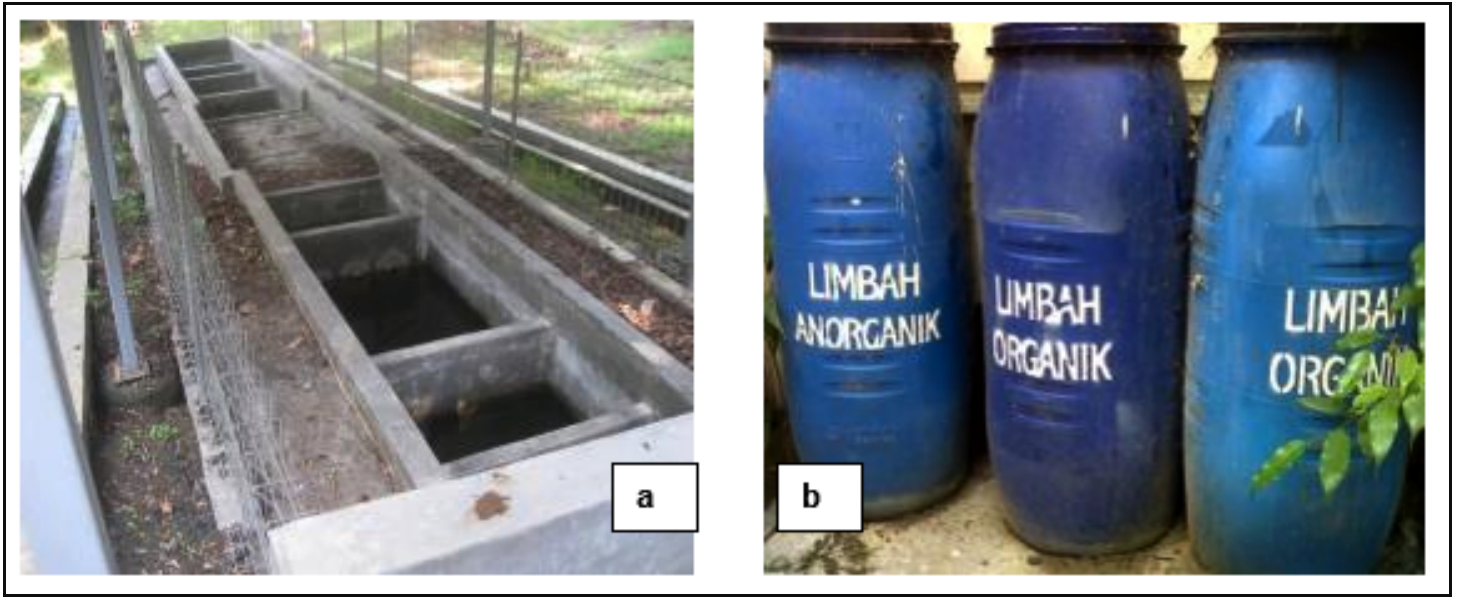

Fig. 5 . (a) Toxic waste treatment pond for decomposition process in the Center of Laboratory in MIPA Faculty. (b) toxic waste treatment by collecting waste into tank

\subsection{Organic waste treatment}

Organic Waste, especially falling leaves and papers is one of the bigest waste resulted from activity in campus. Eventhough most of organic waste management is conducted by private, partneship, there are two units in UNS have been operating composting units for Organic
Waste Treatment. (Fig. 6) shows composting unit in Faculty of Engineering, which produces compos labelled SEMAR for internal use in campus as well as for income generating activity. Apart from that, a Composting Unit also operates in Faculty of Agriculture, which produces $3 \mathrm{~m} 3 /$ day in 7 days composting process. 


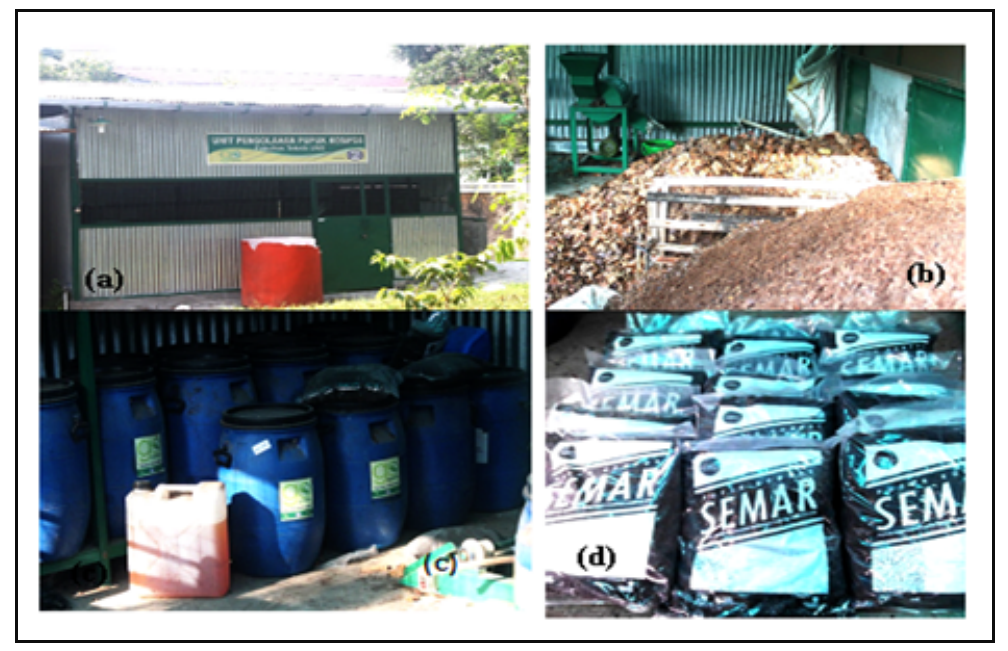

Fig. 6. Composting unit in faculty of engineering

The organic waste of falling leaves in UNS is collected into plastic tank. This process is done by outdoor cleaning service by partnersips with outsourching persons, who also maintain campus to be cleaned, maintained and livable for academic sircumstances. There are 178 units of plastic tank of organic waste collection in UNS campus.

\subsection{Inorganic waste treatment}

Management of inorganic waste in UNS is conducted through the concept of $3 \mathrm{R}$ : Reduce, Reuse Recycle. Inorganic waste especially plastic has become a big problem in UNS for a long time. Most of Faculty units in UNS do not manage inorganic waste individually. However, right now $100 \%$ of faculties and units in UNS separates gargabe collection into organic and inorganic (Fig. 7). This is a part of Rector instruction as follows [3]:

1. All units in UNS should manage garbage collection at least into : organic, inorganic waste, and toxic waste.

2. Universitas sebelas Maret by cooperation with private sector operates inorganic waste recycle.

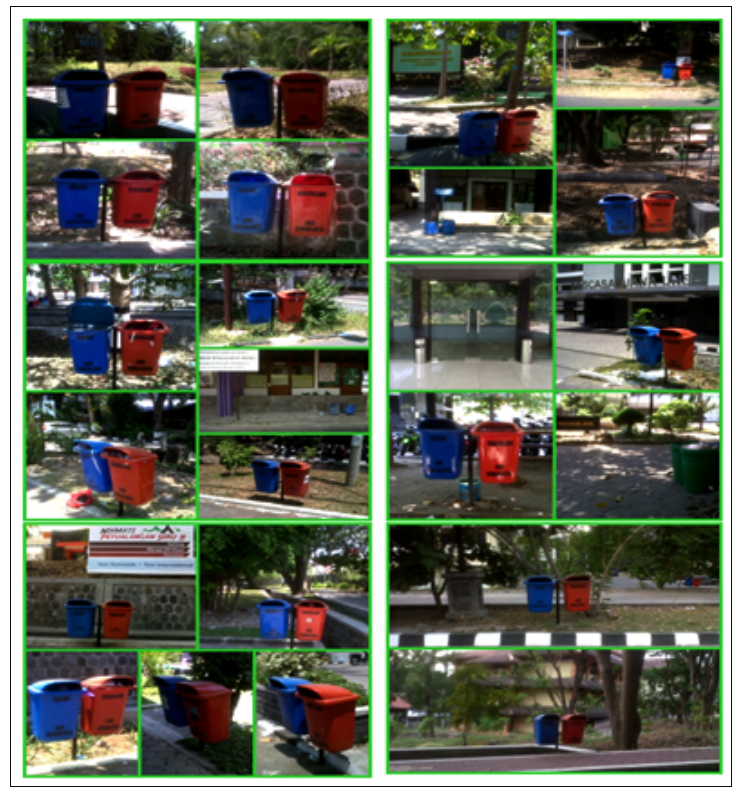

Fig. 7. Separation of inorganic and organic garbage collection

Apart from that, in order to reduce production of inorganic waste, especially from mineral water container, UNS by facilitaion from Ministry of Public Works has built Drinking Water Treatment instalation (SPAM) with 150 spots of water dispensers. The civitas academica is encouraged to bring water tumbler and refill their tumbler in the water dispenser for daily activity in campus (Fig. 8). 

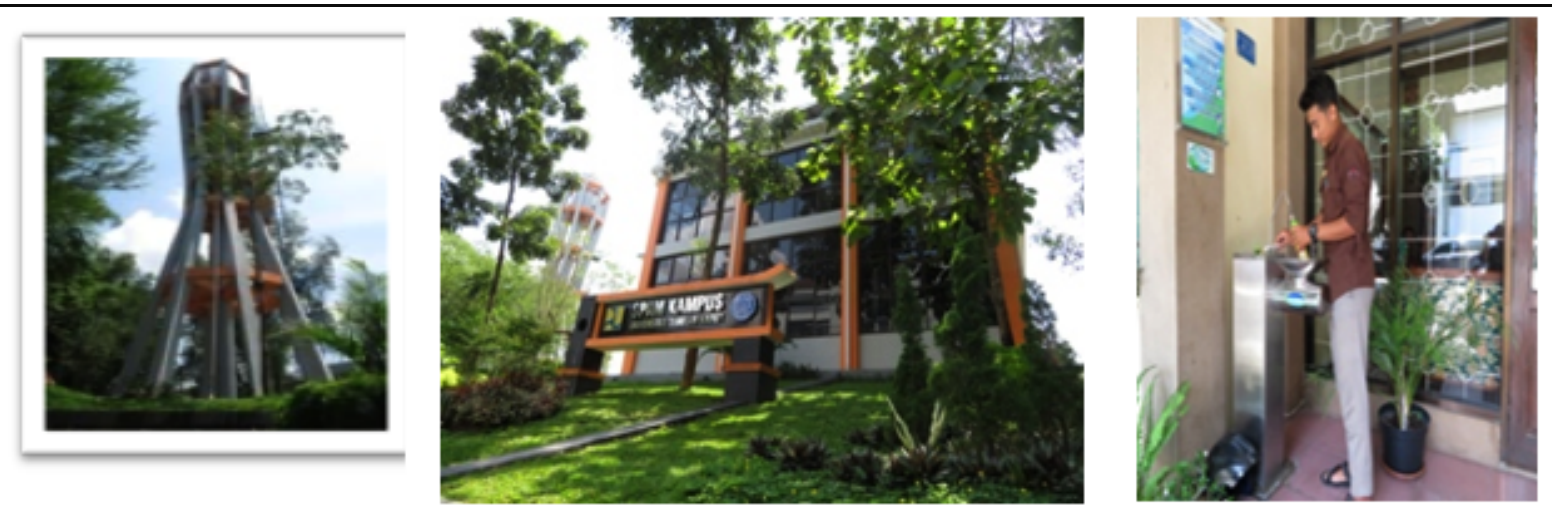

Fig. 8. Drinking water treatment instalation in UNS (SPAM)

\section{Concluding remarks}

Commitment of UNS in achieving sustainable living in campus is expressed through management of waste in Campus . Several programs of Green Campus have been conducted such as Building Domestic Liquid Waste Water Treatment Instalation (IPAL) to proceed domestic liquid waste, from residential areas surounding campus integrated with domestic liquid waste generated by campus activities. Another programs are composting unit instalation to proceed organic waste; toxic waste treatment and inorganic waste treatment. These programs contribute to achieve Goal 6 of Sustainable Development Goals (SDGs): ensure availability and sustainable management of water and sanitation for all.

\section{References}

1. Peraturan Pemerintah Republik Indonesia Nomor 101 Tahun tentang Pengelolaan Limbah Bahan Berbahaya Dan Beracun (2014)

2. United Nations, Sustainable Development Goal 6, Ensure availability and sustainable management of water and sanitation for all. Sustainable Development Knowledeg Platform, .https://sustainabledevelopment.un.org (2015)

3. Green Campus UNS, Matery of Green Campus for Socialization of Green Campus in New Student Orientation Program (2017)

4. Ministry of Public Works and Human Settlements. Standart Operational Procedure IPAL Kawasan Jebres Kota Surakarta (2017) 